\title{
Birds of Alsalam and Abyei-Muglad Principalities West Kordofan State, Sudan
}

Zuheir Nour El Dayem Mahmoud*

Department of Zoology, Faculty of Science, University of Khartoum

DOI: $10.36347 /$ sajb.2020.v08i04.002

| Received: 19.03.2020 | Accepted: 26.03.2020 | Published: 08.04.2020

*Corresponding author: Zuheir Nour El Dayem Mahmoud

\section{Abstract}

Original Research Article

The avifauna of West Kordofan received very little attention. The present study aimed to contribute to birds species recorded for the area and Sudan. Observations were made during May 2011, September 2014, October 2016 and 2019 and facilitated by using a binocular. Documentation was made by a Nikon digital camera. The avifauna of western Kordofan included 78 out of the 653 species recorded for Sudan. The non-passerines species were 55 and the passerines were 23. The order Passeriformes was the largest including 9 families and 23 species. Most Accipitridae, except Milvius migrans, were categorized as endangered or critically endangered; The Secretary Bird (Sagittarius serpentarius) as vagrant; and the Arabian Bustard (Ardeotis arabs), Curlew Sandpiper (Calidris ferruginea) and the African Skimmer (Himantopus flavirostris) as near threatened. The abundance scale adopted in this study ranked these bird species as uncommon. The study concluded that more attention to be paid for studying birds of Sudan especially in conflict and oil fields areas.

Keywords: Birds, Status, Abundance, West Kordofan, Sudan.

Copyright @ 2020: This is an open-access article distributed under the terms of the Creative Commons Attribution license which permits unrestricted use, distribution, and reproduction in any medium for non-commercial use (NonCommercial, or CC-BY-NC) provided the original author and source are credited

\section{INTRODUCTION}

Bowen [1,2] catalogue of Sudan birds, in the Sudan Government Museum is of historical value unlike the bird guide of the Sudan by [3] and the distribution atlas with locality records for most of the Sudan's birds by [4]. Some locality records of birds were published. Of these are bird fauna of Um Bbadr by [5], Hantub [6],Dinder National Park [7]; Khartoum [8], El Ga'ab depression [9], Shendi area [10] and Jabel El Dayer National Park [11]. Electronic list of birds of Sudan, some with images, are available at: [12-15]. In this study birds El Salam and Abyei-Muglad principalities western Kordofan were recorded.

\section{MATERIAL AND METHODS}

The study area, in dotted lines, lies in the southern part of Western Kordofan State ( 11 to $20^{\circ} \mathrm{N}$ and $30^{\circ} 27^{\prime}$ to $\left.32^{\circ} 22^{\prime} \mathrm{E}\right)$ Map 1 . The birds were observed during May 2011, September 2014, October 2015 and 2019 , and facilitated by using an $8 \times 42,123 \mathrm{~m} / 1000 \mathrm{~m}$
Back4prism COMET binocular. Documentation was made by a Nikon digital camera of the type DX (AF-SNIKKOR 18-55mm 1:3.5-5.6G and a 55-200mm 1:4-5.6G ED zoom) in addition to SAMUNG DUOS a smart phone. Identification followed [15-17].

The study considered a species as abundant (A) when over 20 specimens were seen each day in more than one location; common (C) when 10-19 specimens were seen each day in more than one location; fairly common (F) when 5-9 specimens were seen each day in more than one location and uncommon (U) when 1-4 specimens were seen in one location each day or from one location only throughout the study.

Classification and valid species name followed [18] (Table 1). In this study the number of bird species encountered in each family was given as a percentage of species recorded by https://en.wikipedia.org[12]. 


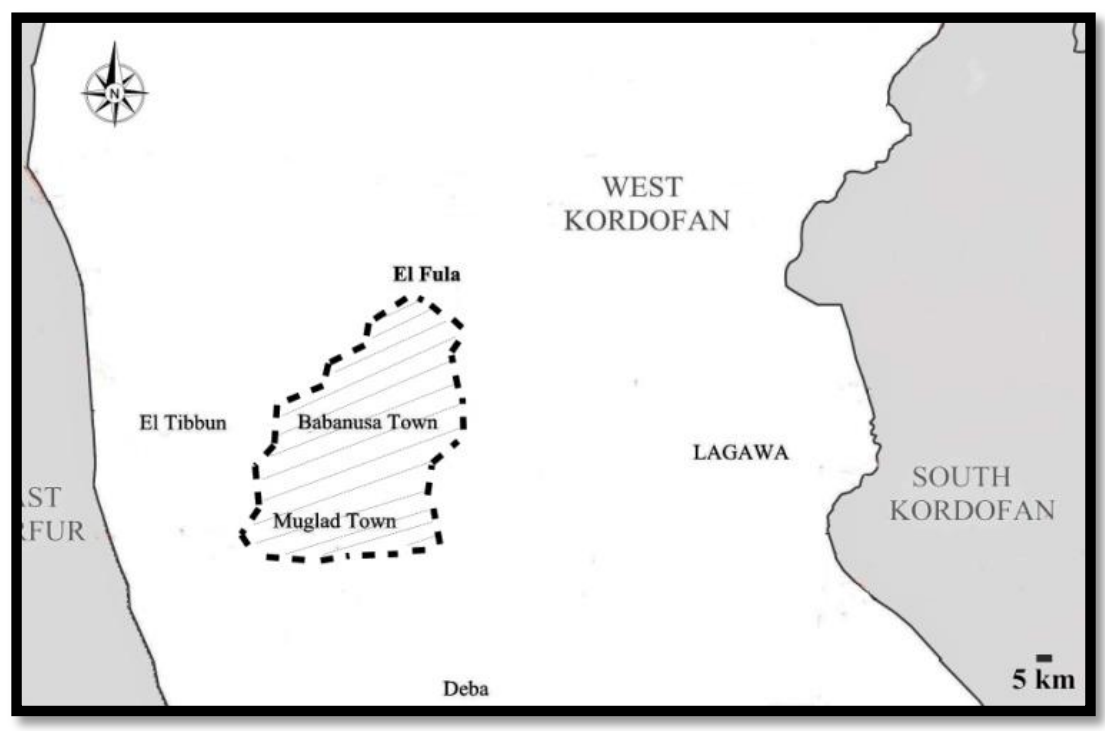

Map-1: The study area is in dotted line. The map was modified From UN Office for the Coordination of Humanitarian Affairs

\section{RESULTS}

The bird species recorded in western Kordofan were given in Table (1). Their status information followed [19] and their categorization was based on [20]. A total of 78 species, 39 families and 16 orders of birds were recorded from the area (Table I). It is apparent from Table 1 that out of 55 non-passeries species, 19 were abundant mostly Columbidae and 19 were uncommon.
Of the 23 Passerines species, 15 were abundant and none was uncommon. The avifauna of western Kordofan included 78 out of the 653 and 631 species recorded for Sudan by $[18,19]$, respectively. Inthis study some bird species might have been missed in view of traipse security restrictions in the oil fields, hiding of some species and irregular visits to the study sites.

Table-1: Birds of El Salam and Abyei-Muglad Principalities Western Kordofan State, with their abundance (AB), status and IUCN red list Categorization (RLC)

\begin{tabular}{|c|c|c|c|c|}
\hline English name & Scientific name & $\mathbf{A B}$ & Status & RLC \\
\hline \multicolumn{5}{|c|}{ Non-passerines species } \\
\hline \multicolumn{5}{|c|}{ Order: Pelecaniformes Family: Ardeidae (17) $29 \%$ were encountered } \\
\hline Grey Heron & Ardea cinerea & $\mathrm{F}$ & RBP & LC \\
\hline Great White Egret & Ardea alba & $\mathrm{F}$ & $\mathrm{P}$ & $\mathrm{LC}$ \\
\hline Little Egret & Egretta garzetta & $\mathrm{F}$ & RBP & LC \\
\hline Squacco Heron & 1.1. Ardeola ralloides & 1.2. $\mathbf{U}$ & RBP & LC \\
\hline Cattle Egret & Bubulcus ibis & $\mathrm{A}$ & MBP & LC \\
\hline \multicolumn{5}{|c|}{ Order: Pelecaniformes Family: Scopidae (1) $100 \%$ were encountered } \\
\hline Hamerkop & Scopus umbretta & $\mathrm{F}$ & RB & $\mathrm{LC}$ \\
\hline \multicolumn{5}{|c|}{ Order: Pelecaniformes Family: Threskiornithidae (6) $17 \%$ were encountered } \\
\hline Sacred ibis & Threskiornis aethiopicus & $\mathrm{A}$ & RBP & $\mathrm{LC}$ \\
\hline \multicolumn{5}{|c|}{ Order: Ciconiiformes Family: Ciconiidae (8) $63 \%$ were encountered } \\
\hline Yellow-billed Stork & Mycteria ibis & $\mathrm{F}$ & MB & $\mathrm{LC}$ \\
\hline Black Stork & Ciconia nigra & $\mathrm{F}$ & PW & LC \\
\hline Abdim's Stork & Ciconia abdimi & A & MB & LC \\
\hline White Stork & Ciconia ciconia & $\mathrm{C}$ & PW & $\mathrm{LC}$ \\
\hline Marabou Stork & Leptoptilos crumeniferus & $\mathrm{A}$ & $\mathrm{RB}$ & LC \\
\hline \multicolumn{5}{|c|}{ Order :Anseriformes Family: Anatidae (23) $13 \%$ were encountered } \\
\hline Egyptian Goose & Alopochen aegyptiaca & $\mathrm{U}$ & MB & $\mathrm{LC}$ \\
\hline Spur-winged Goose & Plectropterus gambensis & $\mathrm{U}$ & MB & LC \\
\hline Pintail & Anas acuta & $\mathrm{U}$ & PW & LC \\
\hline \multicolumn{5}{|c|}{ Order: Accipitriformes Family: Accipitridae (52) $12 \%$ were encountered } \\
\hline Black Kite & Milvus migrans & A & MBPW & $\mathrm{LC}$ \\
\hline Hooded Vulture & Necrosyrtes monachus & $\mathrm{F}$ & $\mathrm{RB}$ & $\mathrm{CE}$ \\
\hline
\end{tabular}


Zuheir Nour El Dayem Mahmoud., Sch Acad J Biosci, April, 2020; 8(4): 81-87

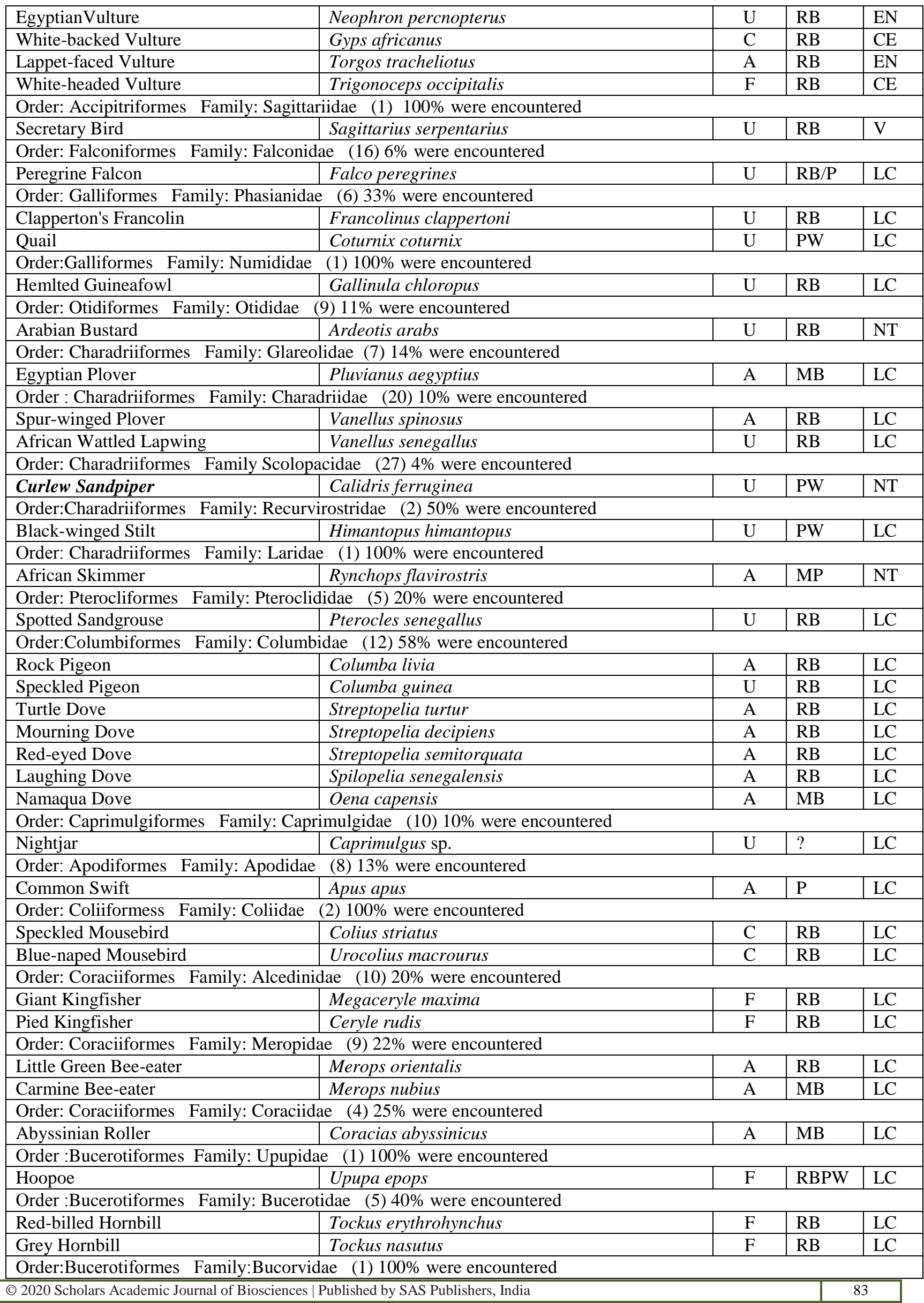


Zuheir Nour El Dayem Mahmoud., Sch Acad J Biosci, April, 2020; 8(4): 81-87

\begin{tabular}{|c|c|c|c|c|}
\hline Abyssinian Ground Hornbill & Bucorvus abyssinicus & $\mathrm{U}$ & RB & $\mathrm{LC}$ \\
\hline \multicolumn{5}{|c|}{ Order: Piciformes Family: Picidae (8) $13 \%$ were encountered } \\
\hline Nubian Woodpecker & Campethera nubica & $\mathrm{U}$ & RB & $\mathrm{LC}$ \\
\hline \multicolumn{5}{|c|}{ Passerines species } \\
\hline \multicolumn{5}{|c|}{ Order: Passeriformes Family: Alaudidae (18) $17 \%$ were encountered } \\
\hline Kordofan Lark & Mirafra cordofanica & A & $\mathrm{R}$ & $\mathrm{LC}$ \\
\hline Desert Lark & Ammomanes deserti & A & RB & LC \\
\hline Crested Lark & Galerida cristata & A & RB & $\mathrm{LC}$ \\
\hline \multicolumn{5}{|c|}{ Order: Passeriformes Family: Motacillidae (11) $18 \%$ were encountered } \\
\hline Yellow Wagtail & Motacilla flava & $\mathrm{C}$ & PW & $\mathrm{LC}$ \\
\hline White Wagtail & Motacilla alba & A & PW & $\mathrm{LC}$ \\
\hline \multicolumn{5}{|c|}{ Order: Passeriformes Family: Pycnonotidae $\quad$ (3) $33 \%$ were encountered } \\
\hline White-vented Bulbul & Pycnonotus barbatus & A & RB & $\mathrm{LC}$ \\
\hline \multicolumn{5}{|c|}{ Order: Passeriformes Family: Corvidae (6) $50 \%$ were encountered } \\
\hline Pied Crow & Corvus albus & A & RB & $\mathrm{LC}$ \\
\hline Fan-tailed Raven & Corvus rhipidurus & $\mathrm{F}$ & RB & $\mathrm{LC}$ \\
\hline Piapiac & Ptilostomus afer & $\mathrm{F}$ & RB & $\mathrm{LC}$ \\
\hline \multicolumn{5}{|c|}{ Order: Passeriformes Family: Sturnidae (11) $18 \%$ were encountered } \\
\hline Ruppell's Starling & Lamprotornis purpuropterus & $\mathrm{C}$ & RB & $\mathrm{LC}$ \\
\hline Long-tailed Glossy Starling & Lamprotornis caudatus & $\mathrm{C}$ & RB & $\mathrm{LC}$ \\
\hline \multicolumn{5}{|c|}{ Order: Passeriformes Family: Ploceidae $\quad$ (20) $25 \%$ were encountered } \\
\hline Little weaver & Ploceus luteolus & $\mathrm{F}$ & RB & $\mathrm{LC}$ \\
\hline Village Weaver & Ploceus cucullatus & A & RB & $\mathrm{LC}$ \\
\hline Northern Masked Weaver & Ploceus taeniopterus & A & RB & LC \\
\hline Red-billed Quelea & Quelea quelea & A & MB & $\mathrm{LC}$ \\
\hline Northern Red Bishop & Euplectes franciscanus & $\mathrm{F}$ & RB & $\mathrm{LC}$ \\
\hline \multicolumn{5}{|c|}{ Order: Passeriformes Family: Estrildidae (14) $14 \%$ were encountered } \\
\hline Red-billed Firefinch & Lagonosticta senegala & $\mathrm{C}$ & RB & $\mathrm{LC}$ \\
\hline African Silverbill & Euodice cantans & A & $\mathrm{RB}$ & LC \\
\hline \multicolumn{5}{|c|}{ Order: Passeriformes, Family: Viduidae (5) $40 \%$} \\
\hline Pin tailed Whydah & Vidua macroura & A & $\mathrm{LC}$ & $\mathrm{RB}$ \\
\hline Sudan Broad-tailed Whydah & Vidua orientalis & A & LC & $\mathrm{RB}$ \\
\hline \multicolumn{5}{|c|}{ Order: Passeriformes Family: Passeridae (11) $27 \%$ were encountered } \\
\hline House Sparrow & Passer domesticus & A & RB & $\mathrm{LC}$ \\
\hline Kordofan Sparrow & Passer cordofanicus & A & $\mathrm{R}$ & $\mathrm{LC}$ \\
\hline Sudan Golden Sparrow & Passer luteus & A & RB & LC \\
\hline
\end{tabular}

Key to status: $\mathrm{B}=\mathrm{Breeding}$ record confirmed; $\mathrm{M}=$ Migrant including on passage through Sudan; $\mathrm{P}=\mathrm{B}$ reeds in Palearctic; $\mathrm{R}=$ Resident; $\mathrm{W}=$ Winters in Sudan; $\mathrm{V}=$ Vagrant.

\section{DISCUSSION}

In western Kordofan the non-passerines species were 55 and the passerines species were 23. The order Passeriformes included 9 families and 19 species followed by Charadriiformes with 5 families and 6 species. Columbiformes included one family Columbidae with 7 species, while 6 orders were represented by one family each, with 1 species each (Table 1). All the 19 Passerines species were categorized as least concern. Out of the 27 Scolopacidae recorded for Sudan by [12] a single specimen of Curlew Sandpiper (C. ferruginea) was found in the study area. It was ranked as near threatened by [19].

Most accipitrids except $M$. migrans, are either as endangered or critically endangered [20]. Sagittarius was ranked as Vagrant and A. Arabs, C. ferruginea and $H$. flavirostris as near threatened.
According to [21] U. epops is the only species which have both a resident breeding population and a wintering population, and $M$. migrans have both a migrant breeding population and a wintering population. Forty seven out of recorded 78 species are resident breeding population. Ardea alba and A. apus breeds in Palearctic while 8 non-passerines and two passerines breeds in the Palearctic and winters in the country (PW) Table 1.

Table I recorded 12 non-passerines and 1 passerine migrants, and 9 non-passerines and 2 passerines Palearctic in the area. The migration strategies of Palearctic Passerines in Africa were critically analyzed by [19] and the Western Palearctic bird species migrating within Africa were listed by [22, 23]. 
Some birds in the study area perform an essential service to plants by dispersal of almost ready to germinate seeds over a wide area. In turn, plants provide goods (nectar, seeds and fruits for particular bird species) and services (nesting sites, nesting material and roosting sites) to a wide spectrum of birds.

Flocks of L. crumeniferus were seen seeking food in burrow pits and dumping areas used by the oil operating companies (Fig. 1). In open grass $C$. abdimi were dominant (Fig. 2).

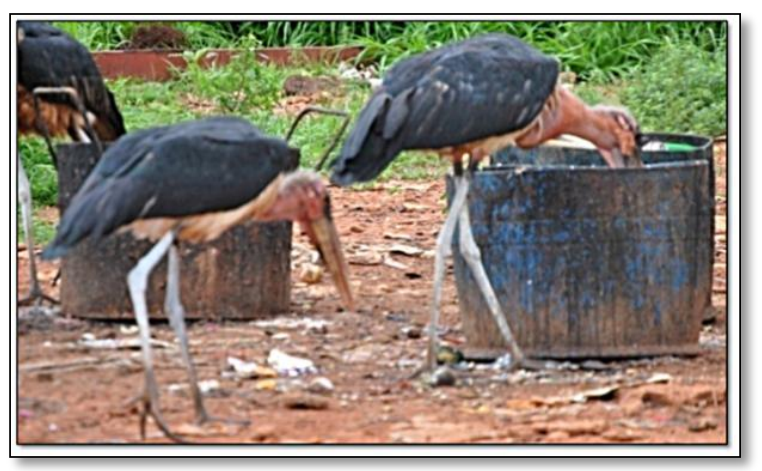

Fig-1: Leptoptilos crumeniferus

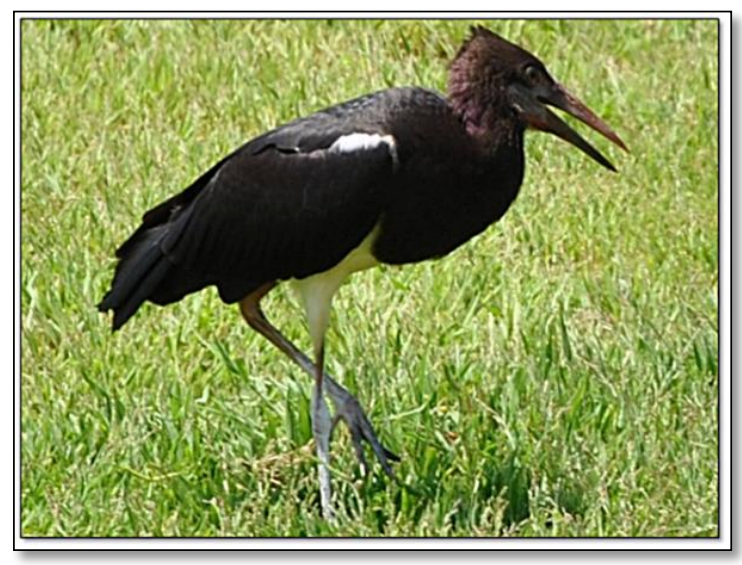

Fig-2: Ciconia abdimi

Vanellus senegallus and B. ibis are associated with open grass land where they seek arthropods. Water birds such as Anas acuta and Scopus umbretta are associated with depressions inundated during the wet season and dominated by floating and emergent vegetation. They wade in water in search of food. Megaceryle maxima (C. rudis and H. flavirostris) skims Wadi Al Galla water surface to catch small tilapias and clarids fish.

Some Accipiteridae aggregates at a distance around slaughtering areas waiting to snatch a piece of meat $M$. migrans or thrown away carrion e. g. $T$. tracheliotus, (Fig. 3). Corvus albus (Fig. 4) and $T$. trachelotus were seen in open grass and garbage sits seeking food.

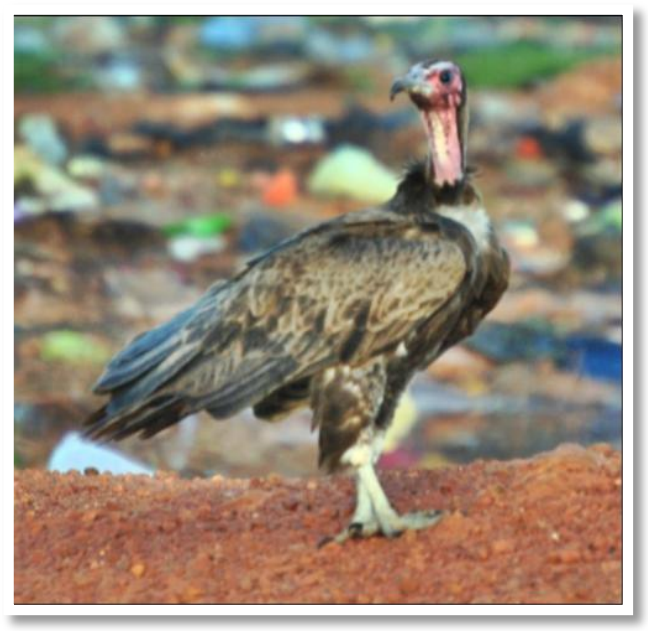

Fig-3: Torgos trachelotus

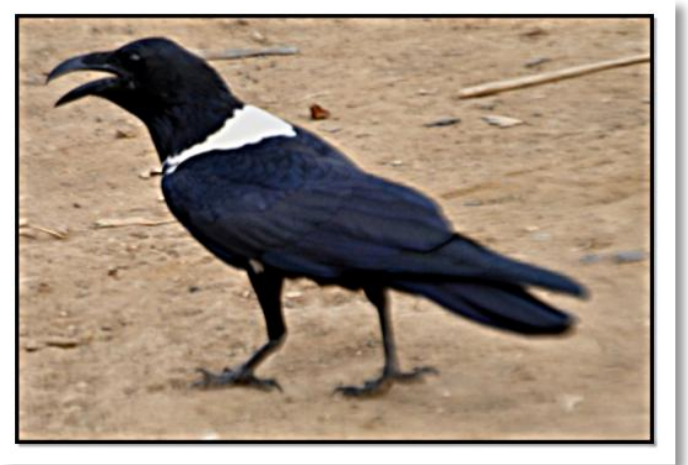

Fig-4: Corvus albus

Quelea quelea are associated with Poaceae (=Gramineae). Passer luteus was seen mostly in shrubs. Streptopelia decipiens, S.senegalensis, O. capensis; G. cristata are associated with bare grassy areas. Euodice cantans (Fig. 5) is often found perching in plants with broad leaves feeding on grass seeds picked from the inflorescences and/or the ground. Tockus erythrohynchus (Fig. 6) and Long-tailed Glossy Starling (L. caudatus) are usually seen in tall trees. Acacia spp., Ziziphus spina-christi and Azadirachtia indica are preferable roosting and nesting site for a number of birds including Doves, P. cucullatus and Scared Ibis Threskiornis aethiopicus (Fig. 7) and roosting site for A. cinerea. Adansonia digitata is a nesting site forstorks. Machineries and tall instillation may be used Fig. 8. 


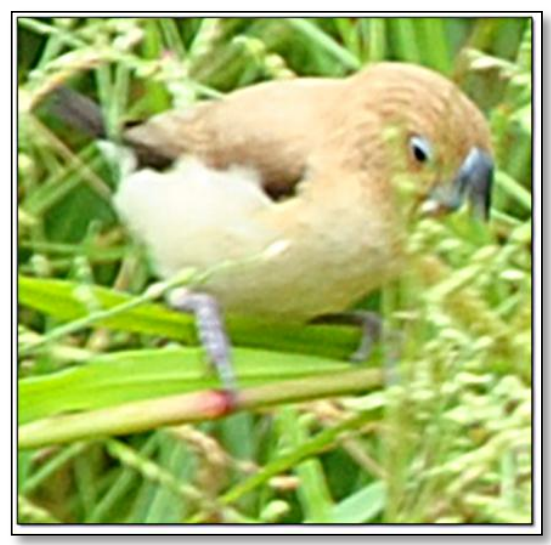

Fig-5: Euodice cantans

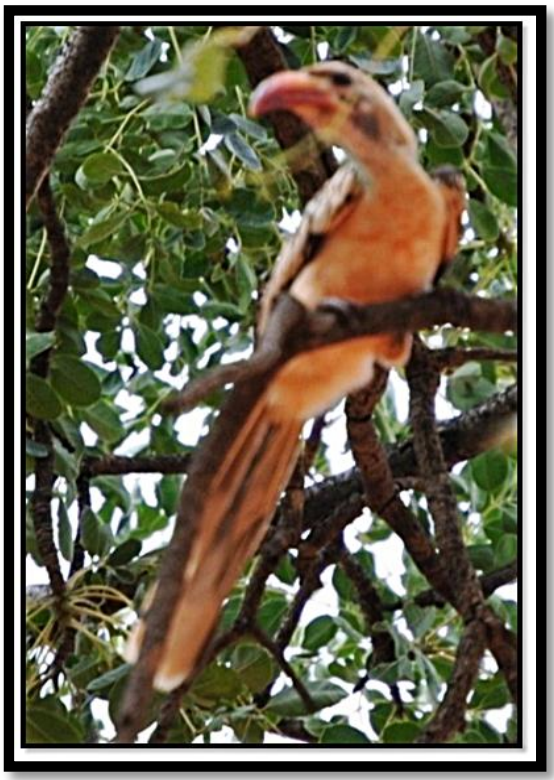

Fig-6: Tockus erythrohynchus

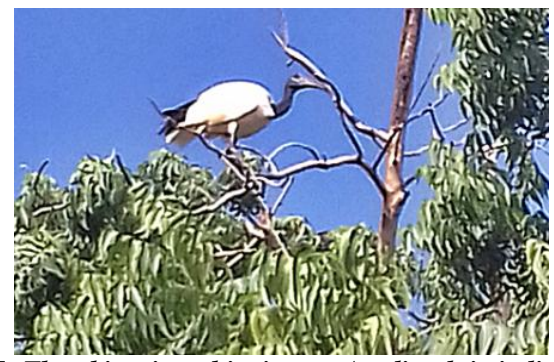

Fig-7: Threskiornis aethiopicuson Azadirachtia indica tree

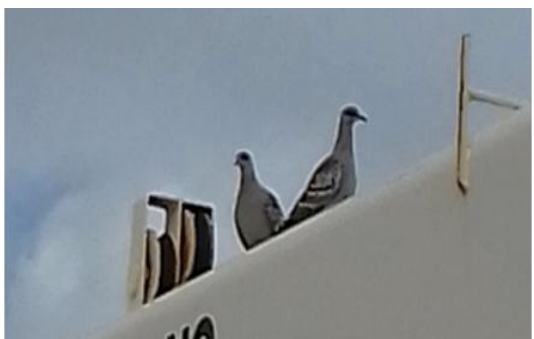

Fig-8: Columba guinea roosting and nesting on a non-working reg.
Pigeons and Kordofan Sparrow are examples of Passerine and Nonpasserine resident species, respectively. One single pair of Speckled Pigeon (Columba guinea) was seen in the study area at a Reg in Sharif (Fig. 8). Rain pools are abundant offering drinking sites for birds (Fig. 9). No birdspecies of the study area were recorded as Vagrant.

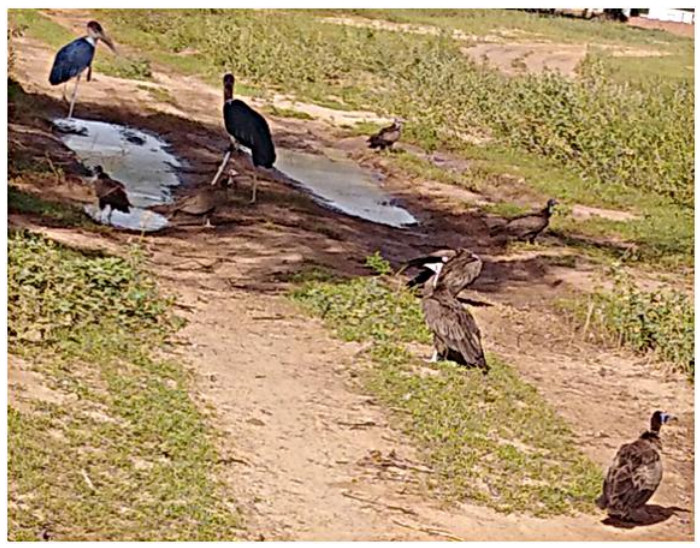

Fig-4: Marabu Stork, Leptoptilos crumeniferus upper left and Ruppell's Vulture Gyps ruppelii lower right

\section{CONCLUSION}

Association between tress assemblage and bird assemblage in forests of West Kordofan and bird adaptability to overcome continuous stresses due to oil exploration and armed tribal conflicts are to be studied.

\section{REFERENCES}

1. Bowen WW. Catalogue of Sudan Birds: Based on the Collection in the Sudan Government Museum (Natural History). Sudan Government; 1926.

2. Bowen WW. Catalogue of Sudan birds, based on the collection in the Sudan Government Museum (Natural History). Part two: Alaudidae to Fringillidae; 1931. Octavo, Publisher.

3. Cave FO and Mac Doland JD. Birds of the Sudan. Oliver and Boyd, Edinburgh; 1955.

4. Nikolaus, G. Distribution Atlas of Sudan's Birds with Notes on Habitat and Status. Bonner Zoologische Monographien, Nr.1987; 25.

5. Mackenzie PZ. A record of the species of birds observed and collected at Um Badr Lake in north-west Kordofan in January, 1955. Sudan Notes and Records. 1955 Dec 1;36(2):176-9.

6. Hamad DM. Bird fauna in Dinder National Park. Sudan Notes \& Records (SNR). 1998;2:187-203.

7. Hamad DM, Evans SM. Seasonal changes in the bird fauna at Hantub. Sudan Notes and Records. 1978 Jan 1;59:176-88.

8. Salah O, Idris E. A note on the bird diversity at two sites in Khartoum, Sudan. Egyptian Academic Journal of Biological Sciences, B. Zoology. 2013 Jun 1;5(1):1-0.

9. Mahmoud ZN, Tahir YF, Hamdeen HM. Birds of El Ga'ab Depression, Sudan. Eur Acad Res. 2015;3(4):4408-15. 
10. Sulieman Y, Pengsakul T, Afifi A, Zakaria MA. Bird diversity in Shendi area, Sudan. Intl J Res Granthaalayah. 2016;4(6):55-63.

11. Adam Sanaa EA. Birds of Jabel El Dayer National Park, Sudan. Accepted for publication in Sudan Biota.2019; 3 .

12. https://en.wikipedia.org org/wiki/List_of_birds_of_Sudan "last edited on 5 September 2018, at 17:15 (UTC)".

13. Birds of Sudan|World-Birds.com. https://www,world-birds.com/birds/a/sudan, accessed 28/8/2019)

14. Sudanbird Checklists. 2014. Avibase - Bird Checklists of the World; Avibase. Accessed 28/11/2019.

15. The Native Birds of Sudan WorldAtlas.comhttps://www.worldatlas.com/article s/the-native-birds-of-sudan.html.Accessed 28/11/2019.

16. Williams JG and Arlott N. A Field Guide to the Birds of East Africa. Collins, London. $6^{\text {th }}$ ed.1986.
17. Hollom PAD, Porter RF. Christensen S and Willis I. Birds of the Middle East and North Africa. T and A. D. Poyser.1988.

18. Stevenson T and Fanshawe, J. Birds of East Africa. Christopher Helm. London. 2002.

19. Dowsett RJ, Atkinson PW and Caddick JA. Checklist of the birds of Sudan; 2018. www.africanbirdclub.org 7/5/2019.

20. Clements JF, Schulenberg TS Iliff MJ Roberson D. The eBird/Clements checklist of birds of the world: v2018.http://www.birds.cornell.edu/clementscheckl ist/download. Accessed 3/7/2019.

21. Iucnredlist.org. 2018.IUCN Red List of Threatened Species.

22. Jones PJ. Migration strategies of Palearctic passerines in Africa. Israel Journal of Ecology and Evolution. 1995 Apr 12;41(3):393-406.

23. Walther BA. List of Western Palearctic bird species migrating within Africa (last updated March 2004). 